2003-10

Stability of intravesical epirubicin

infusion: a sequential temperature study

\title{
Sewell, GJ
}

http://hdl.handle.net/10026.1/3728

10.1046/j.0269-4727.2003.00501.x

Journal of Clinical Pharmacy and Therapeutics

Hindawi Limited

All content in PEARL is protected by copyright law. Author manuscripts are made available in accordance with publisher policies. Please cite only the published version using the details provided on the item record or document. In the absence of an open licence (e.g. Creative Commons), permissions for further reuse of content should be sought from the publisher or author. 


\title{
Stability of intravesical epirubicin infusion: a sequential temperature study
}

\author{
G. J. Sewell ${ }^{*}$ PhD, A. E. Rigby-Jones $\dagger \ddagger$ BSc and M. J. Priston $\dagger \ddagger \mathrm{PhD}$ \\ *Department of Pharmacy and Pharmacology, University of Bath, Claverton Down, Bath, UK, †Pharmacy \\ Department, Derriford Hospital, Plymouth, UK and $¥$ Peninsula Medical School, Tamar Science Park, \\ Plymouth, UK
}

\begin{abstract}
SUMMARY
Objective: To investigate the stability of epirubicin bladder instillation, prepared from two different epirubicin formulations, under refrigerated storage, transportation and clinical use conditions.

Method: A sequential study design was used. Epirubicin instillation $(1 \mathrm{mg} / \mathrm{mL})$ in polypropylene syringes was sequential incubated for periods of 84 days at $8^{\circ} \mathrm{C}$ followed by $2 \mathrm{~h}$ at $25^{\circ} \mathrm{C}$ and $1 \mathrm{~h}$ at $37^{\circ} \mathrm{C}$, the latter two temperatures replicating transport and intravesical conditions, respectively.

Results: The instillation was both chemically and physically stable under those incubation conditions. The formulation of epirubicin used to prepare the instillation infusions did not affect stability.
\end{abstract}

Keywords: epirubicin, intravesical infusion, stability

\section{INTRODUCTION}

The anthracycline antitumour agent, epirubicin, is licensed for intravesical administration to patients with superficial bladder cancer or carcinoma in situ (1). It is also given as prophylaxis against recurrence of malignant disease after transurethal resection (1). Typically, epirubicin is given as a $50 \mathrm{mg}$ in $50 \mathrm{~mL}$ infusion, diluted in $0.9 \%$ sodium chloride (2). Intravesical chemotherapy is admin-

Received 7 November 2002, Accepted 4 July 2003

Correspondence: Professor Graham J. Sewell, Department of Pharmacy and Pharmacology, University of Bath, Claverton Down, Bath, BA2 7AY, UK. Tel.: 01225 826773; fax: 01225 826114; e-mail: prsgjs@bath.ac.uk istered in the oncology outpatient clinic and, to avoid extensive patient waiting times, it is preferable that chemotherapy infusions are prepared in advance (3). The batch preparation of standard chemotherapy doses offers several advantages, including economy of scale and the possibility of prospective QC testing on the batch. In the case of epirubicin bladder instillation, this strategy was precluded by the absence of extended stability data for this presentation.

This study set out to determine the stability of epirubicin intravesical infusion using a sequential temperature protocol. This type of design was selected to reflect the clinical use of intravesical infusions, where following extended storage under refrigerated conditions, infusions would be subjected to transport and equilibration at room temperature for up to $2 \mathrm{~h}$ followed by a residence time of up to $1 \mathrm{~h}$ in the bladder, where the infusion would experience body temperature. Therefore, to simulate worst-case conditions, epirubicin intravesical infusions $(50 \mathrm{mg}$ in $50 \mathrm{~mL} 0.9 \%$ sodium chloride) were stored under dark conditions at $8^{\circ} \mathrm{C}$. At predetermined timepoints over an 84-day period, two syringes were removed for sampling and analysis and were then incubated for a further $2 \mathrm{~h}$ at $25^{\circ} \mathrm{C}$. After sampling and analysis, the syringes were transferred to an incubator at $37^{\circ} \mathrm{C}$ for $1 \mathrm{~h}$ before final sampling and analysis. On completing the final stage of incubation, the epirubicin infusion would have experienced the designated period of refrigerated storage plus the temperature cycling related to transport and clinical use of the infusion. This approach ensured that stability and shelf-life assignments fully accounted for clinical use and would be valid even at the end of the instillation residence time.

Chemical stability was determined by liquid chromatography (LC) assay, using a fully validated stability-indicating method. Physical stability was 
monitored using visual examination for precipitate and colour change, and $\mathrm{pH}$ measurement. Moisture transfer across the syringe was obtained by recording weight changes during incubation. The stability of intravesical infusions prepared from two different proprietory epirubicin presentations was assessed; epirubicin powder (Pharmorubicin Rapid Dissolution) and epirubicin solution (Pharmorubicin Solution, $2 \mathrm{mg} / \mathrm{mL}$ ).

\section{MATERIALS AND METHODS}

\section{Drugs and intravesical infusions}

Epirubicin powder Pharmorubicin Rapid Dissolution, $50 \mathrm{mg}$ vials, Batch 1FP104, Expiry 9/2005, Pharmacia Ltd, Milton Keynes, UK

Epirubicin solutionPharmorubicin solution $2 \mathrm{mg} / \mathrm{mL}$, Batch 201011, Expiry 5/2005, Pharmacia Ltd, UK

Sodium chloride Baxter Healthcare Ltd, Thetford, UK, $0.9 \% \quad$ Batch $02 \mathrm{~F} 10 \mathrm{BD}$, Expiry 5/2004

Intravesical infusions were prepared from either epirubicin powder (designated P) following reconstitution with $25 \mathrm{~mL}$ of $0.9 \%$ sodium chloride infusion or from epirubicin solution (designated S). PVC bags containing $1000 \mathrm{~mL}$ of epirubicin $1 \mathrm{mg} / \mathrm{mL}$ solution were prepared from either the reconstituted powder $(\mathrm{P})$ or the epirubicin solutions (S). After careful mixing, each infusion was drawn up into $14 \times 50 \mathrm{~mL}$ luer-lok Plastipak syringes (Beckton Dickinson, UK), which can be used with a catheter adaptor for administration of bladder instillations. All infusions were prepared, sampled and diluted under EU grade A conditions (4) in a Biomat AC Class II safety cabinet (MAT, Manchester, UK) in accordance with Good Pharmaceutical Manufacturing Practice (4). All other chemicals, solvents and reagents were of high performance liquid chromatography (HPLC) grade from Fisher Scientific, Loughborough, UK.

\section{Stability studies}

Immediately after filling, 14 syringes prepared from each epirubicin presentation, ( $P$ and $S$ ) were transferred to a laboratory refrigerator (LEC, UK) operated at $8 \pm 0 \cdot 2^{\circ} \mathrm{C}$. The syringes were then incubated for $x$ days, and on each sampling day, two syringes of each infusion were sampled and analysed according to the scheme below:

$\begin{array}{ccc}\text { Storage } 8{ }^{\circ} \mathrm{C} & \rightarrow \text { Incubation } 25^{\circ} \mathrm{C} & \rightarrow \text { Incubation } 37^{\circ} \mathrm{C} \\ x \text { days } & 2 \text { hours } & 1 \text { hour } \\ \downarrow & \downarrow & \downarrow \\ \text { Analysis } & \text { Analysis } & \text { Analysis }\end{array}$

where $x=0,3,7,14,28,56$ or 84 days.

\section{Analysis}

pH measurement. Determined with a Denver Instruments digital pH meter (Wolf Laboratories, York, UK) fitted with a glass electrode and calibrated with standard buffer solutions at $\mathrm{pH} 4 \cdot 0,7 \cdot 0$ and $10 \cdot 0$.

Weight change. Weight change during refrigerated storage was determined from initial $(t=0)$ and final $(t=x)$ weights of each prefilled syringe prior to sampling using a Ohaus Analytical Plus analytical balance (European Instruments, Oxford, UK).

Visual appearance. Syringes were examined under normal laboratory lighting against white and black backgrounds for the presence of particulate matter and for any change in the colour of infusions.

\section{Liquid chromatography}

LC hardware. Spectrasystem P2000 isocratic pump, Spectrasystem UV 6000 LP diode array UV detector, Spectrasystem AS3000 autosampler, ChromQuest data handling software, all from ThermoFinnigan Ltd, Stoke-on-Trent, Staffs, UK.

LC column. Stainless steel $250 \times 4.6 \mathrm{~mm}$ diameter, packed with Hypersil $5 \mu \mathrm{m}$ CN, HPLC Technology Ltd, Macclesfield, UK.

Mobile phase. $14 \%(\mathrm{v} / \mathrm{v})$ acetonitrile, $30 \%(\mathrm{v} / \mathrm{v})$ methanol, $56 \%$ phosphoric acid $(0.085 \% \mathrm{w} / \mathrm{v})$, containing sodium dodecyl sulphate $(0 \cdot 2 \% \mathrm{w} / \mathrm{v})$. Flow rate $=1.2 \mathrm{~mL} / \mathrm{min}$. 

Injection volume. $20 \mu \mathrm{L}$ (Rheodyne loop-value) of sample via Spectrasystem AS3000 autosampler, previously diluted 1-100 with ethylenediaminetetraacetic acid (EDTA) $(0 \cdot 1 \% \mathrm{w} / \mathrm{v}) /$ ascorbic acid $(0 \cdot 15 \% \mathrm{w} / \mathrm{v})$ solution.

Detection: UV, $256 \mathrm{~nm}$. Epirubicin standard: Pharmorubicin solution diluted to $10 \mu \mathrm{g} / \mathrm{mL}$ with EDTA $(0 \cdot 1 \% \mathrm{w} / \mathrm{v}) /$ ascorbic acid $(0 \cdot 15 \% \mathrm{w} / \mathrm{v})$, used as external standard with bracketing injection technique.

\section{LC METHOD VALIDATION}

Linearity of response: A 5-point calibration plot was prepared from duplicate injections at each epirubicin concentration over a range $7 \cdot 5-22.5 \mu \mathrm{g} / \mathrm{mL}$. The mean peak area for each concentration was recorded and plotted against concentration. Least squares regression equation: $y=$ $91050 x+8384$.

$$
\text { Correlation coefficient }(r)=0.999 \text {. }
$$

Precision of LC system. Replicate injections of a $10 \mu \mathrm{g} / \mathrm{mL}$ epirubicin standard solution were made in sequence and the peak area recorded in each case:

$$
\mathrm{CV}=0.69 \%, \quad n=7 .
$$

Precision of LC method. Seven replicate dilutions to $10 \mu \mathrm{g} / \mathrm{mL}$ were prepared from a $1 \mathrm{mg} / \mathrm{mL}$ epirubicin stock solution. Each solution was injected in duplicate on to the LC system and the mean peak area obtained for each solution was recorded.

$$
\mathrm{CV}=1.23 \%, \quad n=7 \text {. }
$$

Inter-day precision of LC method. A $1 \mathrm{mg} / \mathrm{mL}$ epirubicin stock solution was diluted to $10 \mu \mathrm{g} / \mathrm{mL}$ with EDTA $(0 \cdot 1 \% \mathrm{w} / \mathrm{v}) /$ ascorbic acid $(0 \cdot 15 \% \mathrm{w} / \mathrm{v})$ on 7 days over a 34-day period and injected, in duplicate, onto the LC system. The mean peak area obtained on each day was recorded.

$$
\mathrm{CV}=0.79 \%, \quad n=7 \text {. }
$$

\section{ACCURACY}

The QC samples (blinded to the operator) containing epirubicin at concentrations of either 0.5 or $1 \mathrm{mg} / \mathrm{mL}$ were subjected to the LC assay, in duplicate. The accuracy of the concentration found
Table 1. Accuracy of LC determination of epirubicin QC solutions

\begin{tabular}{lll}
\hline $\begin{array}{l}\text { Epirubicin } \mathrm{HCl} \\
\text { added }(\mathrm{mg} / \mathrm{mL})\end{array}$ & $\begin{array}{l}\text { Epirubicin } \mathrm{HCl} \\
\text { found }(\mathrm{mg} / \mathrm{mL})^{\mathrm{a}}\end{array}$ & $\begin{array}{l}\text { Accuracy } \\
(\%)\end{array}$ \\
\hline 1.0 & 1.024 & $102 \cdot 4$ \\
0.5 & 0.501 & 102.0 \\
\hline
\end{tabular}

a Mean of duplicate determinations.

was determined with respect to the concentration of epirubicin $\mathrm{HCl}$ added (see Table 1).

Stability indication. Volumetric flasks $(10 \mathrm{~mL})$ containing $1.0 \mathrm{~mL}$ epirubicin solution, $(100 \mu \mathrm{g} / \mathrm{mL})$ plus $1.0 \mathrm{~mL}$ of either $0 \cdot 1 \mathrm{~m}$ sodium hydroxide, $0 \cdot 1 \mathrm{M}$ hydrochloric acid or 1 volume $\mathrm{H}_{2} \mathrm{O}_{2}$ were incubated at $65^{\circ} \mathrm{C}$ for $1 \mathrm{~h}$. After incubation, each flask was cooled to $25^{\circ} \mathrm{C}$ and the flasks containing $0.1 \mathrm{M} \mathrm{HCl}$ and $0.1 \mathrm{M} \mathrm{NaOH}$ were neutralized with equal volumes of $0 \cdot 1 \mathrm{M} \mathrm{NaOH}$ and $0 \cdot 1 \mathrm{M} \mathrm{HCl}$, respectively. Each flask was then adjusted to volume with water and subjected to LC assay against a control solution containing $1.0 \mathrm{~mL}$ epirubicin solution $100 \mu \mathrm{g} / \mathrm{mL}$, which had been stored at $4^{\circ} \mathrm{C}$ for $1 \mathrm{~h}$ prior to equibration to room temperature and adjusted to volume with water.

Table 2 (below) shows the fraction epirubicin remaining with respect to the control solution (as percent remaining).

It was concluded that the LC assay gave a linear analytical response and was of adequate precision and accuracy for this study. The assay was also stability indicating for epirubicin $\mathrm{HCl}$, which was particularly sensitive to acid/base-catalysed degradation at elevated temperature. All degradation product peaks were clearly resolved from the epirubicin peak.

Table 2. Fraction of epirubicin concentration remaining after stress treatments with respect to the control solution

\begin{tabular}{lcl}
\hline Treatment & $\begin{array}{l}\text { \% Remaining } \\
\text { wrt control }\end{array}$ & $\begin{array}{l}\text { Presence of degradation } \\
\text { peaks }(\mathrm{Y} / \mathrm{N})\end{array}$ \\
\hline $0 \cdot 1 \mathrm{M} \mathrm{NaOH}$ & 0 & $\mathrm{Y}$ \\
$0 \cdot 1 \mathrm{M} \mathrm{HCl}$ & $59 \cdot 4$ & $\mathrm{Y}$ \\
$1 \mathrm{vol} \mathrm{H} \mathrm{O}_{2}$ & $96 \cdot 4$ & $\mathrm{~N}$ \\
Control & $100 \cdot 0$ & $\mathrm{~N}$ \\
\hline
\end{tabular}




\section{RESULTS AND DISCUSSION}

Chemical and physical stability data for eprubicin intravesical infusion, prepared from both lyophi- lized powder and solution presentations, are shown in Tables 3 and 4, respectively. From Table 3 , it is evident that over a period of 84 days refrigerated storage, followed by 2 - $h$ incubation at

\begin{tabular}{|c|c|c|c|c|}
\hline \multirow[b]{2}{*}{$\begin{array}{l}\text { Epirubicin } \\
\text { presentation }^{\mathrm{a}}\end{array}$} & \multirow[b]{2}{*}{$\begin{array}{l}\text { Storage time } \\
\text { at } 8^{\circ} \mathrm{C}=x \text { days }\end{array}$} & \multicolumn{3}{|c|}{$\begin{array}{l}\text { Epirubicin remaining } \\
(\% \text { of initial concentration })^{b}\end{array}$} \\
\hline & & $\begin{array}{l}x \text { days } \\
\text { at } 8^{\circ} \mathrm{C}\end{array}$ & $\begin{array}{l}+2 \mathrm{~h} \\
\text { at } 25^{\circ} \mathrm{C}\end{array}$ & $\begin{array}{l}+1 \mathrm{~h} \\
\text { at } 37^{\circ} \mathrm{C}\end{array}$ \\
\hline $\mathrm{P}$ & 0 & $100 \cdot 0$ & $99 \cdot 1$ & 101.9 \\
\hline S & & $100 \cdot 0$ & $104 \cdot 4$ & $101 \cdot 5$ \\
\hline$P$ & 3 & $96 \cdot 1$ & $97 \cdot 2$ & $97 \cdot 7$ \\
\hline$S$ & & $101 \cdot 1$ & $102 \cdot 3$ & $99 \cdot 6$ \\
\hline$P$ & 7 & $96 \cdot 9$ & $102 \cdot 5$ & $101 \cdot 2$ \\
\hline S & & 98.5 & $101 \cdot 3$ & $101 \cdot 3$ \\
\hline$P$ & 14 & $100 \cdot 3$ & 98.9 & $102 \cdot 7$ \\
\hline S & & $100 \cdot 4$ & $100 \cdot 3$ & $103 \cdot 5$ \\
\hline$P$ & 28 & $101 \cdot 2$ & $103 \cdot 4$ & $104 \cdot 8$ \\
\hline S & & $101 \cdot 1$ & $102 \cdot 6$ & $105 \cdot 0$ \\
\hline $\mathrm{P}$ & 56 & $100 \cdot 7$ & $100 \cdot 8$ & $101 \cdot 1$ \\
\hline$S$ & & $105 \cdot 0$ & $104 \cdot 4$ & $104 \cdot 6$ \\
\hline $\mathrm{P}$ & 84 & $101 \cdot 6$ & $100 \cdot 9$ & $99 \cdot 8$ \\
\hline$S$ & & $100 \cdot 3$ & $103 \cdot 4$ & $100 \cdot 6$ \\
\hline
\end{tabular}

Table 3. Chemical stability of epirubicin bladder installation $(50 \mathrm{mg} / \mathrm{mL})$ after various refrigerated storage times followed by incubation for $2 \mathrm{~h}$ at $25^{\circ} \mathrm{C}$ and $1 \mathrm{~h}$ at $37^{\circ} \mathrm{C}$

a Presentation from which epirubicin bladder instillation prepared, where $\mathrm{P}=$ pharmorumorubicin rapid dissolution powder and $\mathrm{S}=$ pharmorubicin solution.

${ }^{\mathrm{b}}$ Mean of duplicate results.

Table 4. Physical stability of epirubicin bladder instillation $(50 \mathrm{mg} / \mathrm{mL})$ following refrigerated storage at various times followed by incubation for $2 \mathrm{~h}$ at $25^{\circ} \mathrm{C}$ and $1 \mathrm{~h}$ at $37^{\circ} \mathrm{C}$

\begin{tabular}{|c|c|c|c|c|}
\hline $\begin{array}{l}{ }^{a} \text { Epirubicin } \\
\text { presentation }\end{array}$ & $\begin{array}{l}\text { Storage time at } \\
8^{\circ} \mathrm{C}=x \text { days }\end{array}$ & $\begin{array}{l}\text { Weight change after } \\
x \text { days at } 8^{\circ} \mathrm{C}(\%)\end{array}$ & $\begin{array}{l}\mathrm{pH} \text { after } x \text { days at } \\
8^{\circ} \mathrm{C}+2 \mathrm{~h} \text { at } 25^{\circ} \mathrm{C} \\
+1 \mathrm{~h} \text { at } 37^{\circ} \mathrm{C}\end{array}$ & $\begin{array}{l}\text { Appearance after } x \text { days } \\
\text { at } 8^{\circ} \mathrm{C}+2 \mathrm{~h} \text { at } 25^{\circ} \mathrm{C} \\
+1 \mathrm{~h} \text { at } 37^{\circ} \mathrm{C}\end{array}$ \\
\hline $\mathrm{P}$ & 0 & $<0 \cdot 1$ & 4.97 & + \\
\hline$S$ & & $<0 \cdot 1$ & $3 \cdot 42$ & + \\
\hline$P$ & 3 & $<0 \cdot 1$ & $5 \cdot 03$ & + \\
\hline S & & $<0 \cdot 1$ & $3 \cdot 39$ & + \\
\hline $\mathrm{P}$ & 7 & $<0 \cdot 1$ & $4 \cdot 84$ & + \\
\hline$S$ & & $<0 \cdot 1$ & $3 \cdot 48$ & + \\
\hline $\mathrm{P}$ & 14 & $<0 \cdot 1$ & 5.00 & + \\
\hline$S$ & & $<0 \cdot 1$ & $3 \cdot 43$ & + \\
\hline $\mathrm{P}$ & 28 & $<0 \cdot 1$ & ND & + \\
\hline$S$ & & $<0.1$ & ND & + \\
\hline$P$ & 56 & $<0 \cdot 1$ & 5.04 & + \\
\hline$S$ & & $<0.1$ & 3.45 & + \\
\hline $\mathrm{P}$ & 84 & $<0.1$ & 4.99 & + \\
\hline$S$ & & $<0 \cdot 1$ & $3 \cdot 41$ & + \\
\hline
\end{tabular}

P, pharmorubicin rapid dissolution powder; S, pharmorubicin solution; +, clear, red solution with no visible particulates; ND, not done. 
$25^{\circ} \mathrm{C}$ and $1 \mathrm{~h}$ at $37^{\circ} \mathrm{C}$, the drug assay did not vary from the initial concentration by more than $\pm 5 \%$. The physical stability characteristics (Table 4) were also unchanged over the study period. Although the $\mathrm{pH}$ value of intravesical infusion prepared from the Pharmorubicin Rapid Dissolution powder was approximately 1.5 units higher than the infusions prepared from Pharmorubicin solution, the $\mathrm{pH}$ of both sets of infusions did not change significantly with time. The differences in formulation between the two Pharmorubicin presentations did not influence the stability of infusions and did not affect the LC assay used to quantify epirubicin in any way.

The slight trend towards increased epirubicin assay value at extended storage/incubation time (but still within $5 \%$ of initial concentration), could not be explained by water loss from the syringes as there was no significant change in weight. However, it is possible that water could have been taken up by syringe components, but not transmitted to the environment outside the syringe. This would be consistent with the observed increase in drug concentration, but absence of significant weight change. To replicate pharmaceutical and clinical practice, no attempt was made to control external humidity in this study.

The sequential temperature-cycling design of this study enabled all conditions experienced by the infusion, before and during use, to be included in the stability assessment. This avoids the uncertainty of speculative addition of changes in chemical and physical stability under storage and in-use conditions, which is necessary in studies of the conventional parallel temperature design.

In conclusion, this study has demonstrated that epirubicin $50 \mathrm{mg} / 50 \mathrm{~mL}$ intravesical infusion in polyproplylene syringes is physically and chemically stable under refrigerated storage at $8^{\circ} \mathrm{C}$ for up to 84 days followed by $2 \mathrm{~h}$ at $25^{\circ} \mathrm{C}$ and $1 \mathrm{~h}$ at $37^{\circ} \mathrm{C}$ to simulate $2 \mathrm{~h}$ transportation time and $1 \mathrm{~h}$ resident time in the bladder, respectively. As was the case in this study, epirubicin infusions should always be protected from light.

\section{REFERENCES}

1. Medicines Compendium (2002) London, UK: Datapharm Publications Ltd.

2. Allwood M, Stanley A, Wright P (eds) (2002) The Cytotoxic Handbook, 4th edn. Oxford, UK: Radcliffe Medical Press.

3. Plumridge RJ, Sewell GJ (2001) Dose-banding of cytotoxic drugs: a new concept in cancer chemotherapy. American Journal of Health-system Pharmacy, 58, 1760-1764.

4. Rules and Guidance for Pharmaceutical Manufacturers and Distributors (1997) London: The Stationery Office. 